\title{
РАЗДЕЛ ХХХІІ. КРАЕВЕДЕНИЕ
}

\author{
Григорьева Н.С. ${ }^{1,2}$ \\ Работа с детьми в Хакасском областном краеведческом музее в начале 1980-х гг. \\ ${ }^{1}$ Институт истории и права ФГБОУ ВО «Хакасский государственный \\ университет им. Н.Ф. Катанова» \\ ${ }^{2}$ МБДОУ «Детский сад «Дюймовочка» \\ (Россия, Абакан)
}

doi: $10.18411 / \mathrm{j}-07-2020-190$

idsp: ljournal-07-2020-190

Научный руководитель

Готлиб А.И.

\section{Аннотация}

В данной статье проанализированы отчеты о работе Хакасского областного краеведческого музея за 1980-83 гг. Какая проводилась работа с детьми в соответствующую историческую эпоху.

Ключевые слова: Хакасский краеведческий музей, экскурсия, экспозиция, Хакасия, Хакасия в древности, Древнехакасское государство, Каменные изваяния эпохи ранней бронзы, работа с детьми в музее.

\section{Abstract}

This article analyzes the reports on the work of the Khakass Regional Museum of Local Lore for 1980-83. What work was carried out with children in the corresponding historical era.

Keywords: Khakass Museum of Local Lore, excursion, exposition, Khakassia, Khakassia in antiquity, Ancient Khakass state, Stone statues of the Early Bronze Age, work with children in the museum.

Дети - основная категория посетителей большинства музеев мира и СССР в этом не был исключением. В большинстве музеев детская аудитория составляет больше половины количества посетителей. Поэтому в музейной методической литературе советского периода встречается много работ, посвященных тематике организации работ с детьми в музеях и их специфике. Как это происходило на практике в начале 1980-х гг., мы узнаем, проанализировав отчеты о работе Хакасского областного краеведческого музея за 1980-83 гг.

Для начала познакомимся с таблицей некоторых данных о работе музея за указанный период:

Таблича 1.

Работа музея за 1980-83 г2.

\begin{tabular}{|c|c|c|c|c|}
\hline Год & $\begin{array}{l}\text { Количество } \\
\text { посетителей }\end{array}$ & $\begin{array}{c}\text { Количество } \\
\text { экскурсий и } \\
\text { человек на них } \\
\end{array}$ & $\begin{array}{c}\text { Количество экскурсий для } \\
\text { учащихся городских и } \\
\text { сельских школ } \\
\end{array}$ & $\begin{array}{c}\text { Мероприятия для } \\
\text { школьников и учащейся } \\
\text { молодежи } \\
\end{array}$ \\
\hline 1980 & 48500 & $\begin{array}{c}1054 \\
24795 \text { чел. }\end{array}$ & $\begin{array}{c}543 \\
12949 \text { уч. } \\
\end{array}$ & 30 \\
\hline 1981 & 70192 & $\begin{array}{c}1057 \\
23547 \text { чел. }\end{array}$ & $\begin{array}{c}601 \\
14543 \text { уч. } \\
\end{array}$ & 30 \\
\hline 1982 & 83319 & $\begin{array}{c}12297 \\
28079 \text { чел. }\end{array}$ & $\begin{array}{c}839 \\
19313 \text { уч. }\end{array}$ & 37 \\
\hline 1983 & 96551 & $\begin{array}{c}1707 \\
34733 \text { чел. } \\
\end{array}$ & $\begin{array}{c}1106 \\
20900 \text { уч. }\end{array}$ & 30 \\
\hline
\end{tabular}


Как мы видим, учет учащихся велся только в организованных группах для экскурсий. Сколько детей посетило музей без экскурсий неизвестно. Если в 1980 г. школьники составляли лишь половину посетителей музея, охваченных экскурсиями, то в 1983 г. они составляют уже две трети.

В 1980 г. проведено 30 мероприятия и из них непосредственно детям посвящены пионерские сборы «Герои не умирают», «Поэт - воин, солдат», «Этот день Победы порохом пропах». Эти мероприятия имеют большое эмоциональное и нравственное значение. Живое слово ветеранов волнует, глубоко западает в душу и надолго остается в памяти ребенка. К примеру, в 1980 г. хорошо прошла встреча с жителями Хакасии кавалерами Ордена Ленина, посвященная 110-летию со дня рождения В.И. Ленина, на которой присутствовали Герой Социалистического Труда Кандибор А.И. - кавалер 4-х Орденов Ленина, заслуженная учительница РСФСР Барашкова И.А. Встреча проходила в зале музея на выставке «Достоин высшей награды Родины», посвященной землякам, награжденным орденом Ленина. Ребята узнали имена прославленных людей области, выслушали выступления орденоносцев и сами прочитали ветеранам стихи и подарили им сувениры.

Так же в этом году с участием учеников национальной школы создан клуб «Юный историк и краевед», разработана программа клуба и ежемесячно проводились заседания. Проведен ряд встреч с интересными людьми, школьники изучали историю Хакасии, готовили экскурсоводов, собирали материал для своего школьного музея.

В 1981 г. на базе музея начал работу кружок «Юный археолог» школы №19. С учащимися этой школы проведено несколько занятий, прочитаны лекции с показом археологических предметов по теме: «Хакасия в древности», «Древнехакасское государство», «Каменные изваяния эпохи ранней бронзы».

Для школьников, учащихся училищ, школы ДОСААФ проведено 30 мероприятий. На этих мероприятиях выступали ветераны труда, ветераны войны. Например, с ветераном Великой Отечественной войны, участником битвы под Москвой Д.И. Нагрузовым. Встреча была посвящена 40-летию битвы под Москвой.

В 1982 г. школам предоставляется широкая возможность использовать Хакасский краеведческий музей в учебной и воспитательной работе. По всем школам города и многим школам области распространена тематика школьных экскурсий по истории и обществоведению. В музее разработана тематика экскурсий согласно учебным программам по истории и обществознанию, биологии.

С администрацией 17 школ города были заключены договоры на 1982 - 1983 учебный год на экскурсионное обслуживание в музее. На основе анализа статистики можно было сделать некоторые выводы: не все школы г. Абакана активно использовали экспозиции музея для изучения школьной программы. Так учащиеся школы № 10 побывали в музее 18 раз, школы № 19 - 14 раз, школы № 30 - 13 раз. Тогда как школа №7 - только 1 раз, а школы №4 и №18 по 2 раза.

В 1982 году были разработаны 7 новых экскурсий по школьной программе: «История жизни на земле» (для 9 классов), «Культура области за годы советской власти» (для 9 классов), «Боевой путь 309-й Пирятинской дивизии» (для 10 классов).

Музей организовывал встречу школьников национальной школы с ветераном труда Добровым С.К., встречу школьников школы №30 с художником Бутонаевым В.П.

В 1983 году большинство мероприятий было посвящено знаменательным датам и юбилеям: 40-летию прорыва блокады г. Ленинграда, 38-й годовщине со Дня Победы, 80-летию со дня рождения основателя хакасской драматургии А.М. Топанова, 65-летию Ленинского комсомола.

Это также вечера, встречи, пионерские сборы, классные часы, праздники, собрания. 
Особенно запомнились мероприятия: встречи сандружинниц 309-й Пирятинской дивизии со студентами медучилища, участников Парада Победы с учащимися ДОСААФ, поэтический вечер, посвященный А.М. Топанову, где учащиеся национальной школы читали его стихи, встреча с пограничниками области, встреча «Красива земля, когда сердцем согрета» учащихся сельскохозяйственного техникума с передовиками сельского хозяйства Алтайского района; классные часы по охране природы, комсомольские собрания и др.

В целом, как мы видим, работа с детьми в Хакасском краеведческом музее в указанный период ведется активно и разнообразными формами, хотя и несколько идеализировано, что полностью соответствует исторической эпохи в развитии страны. Но из созданных за этот период выставок и постоянных экспозиций ни одна напрямую или целиком не ориентирована на детей. Но нужно учитывать, что в 1973 году музей переехал в новое здание и до 1984 г. еще создавались постоянные экспозиции. Тем не менее, работа со школьниками, особенно с учащейся молодежью, как мы видим, велась очень активно и имела большое эмоциональное и нравственное значение. На мероприятиях, проходивших в музее, ребята не только обогащали свои знания, но учились мужеству, стойкости, уважению к труду, учились любить свою Родину.

Многое из музейных форм работы с детьми в 1990-е годы было утеряно или забыто, а сейчас возрождается заново.

Следует отметить, что в указанный период времени прослеживается отсутствие в практике работы Хакасского краеведческого музея какой-либо целенаправленной работы с детьми с ограниченными возможностями и детьми маленьких возрастных групп - детсадовского возраста, начальных классов.

$$
* * *
$$

1. Отчет о работе Хакасского областного музея за 1980 год. Архив ХНКМ им. Л.Р. Кызласова. Стр. $11-15$.

2. Отчет о работе Хакасского областного музея за 1980 год. Архив ХНКМ им. Л.Р. Кызласова. Стр. $10-13$.

3. Отчет о работе Хакасского областного музея за 1980 год. Архив ХНКМ им. Л.Р. Кызласова. Стр. $11-17$.

4. Отчет о работе Хакасского областного музея за 1980 год. Архив ХНКМ им. Л.Р. Кызласова. Стр. $13-18$.

\author{
Пряникова Е.В. ${ }^{1}$, Мишарина А..Л. ${ }^{2}$ \\ Вклад врача акушера-гинеколога Кызласовой Клары Романовны в развитие \\ здравоохранения Республики Хакасия \\ ${ }^{1}$ ФГБОУ ВО «Хакасский государственный университет им. Н.Ф. Катанова» \\ ${ }^{2}$ ГАУК РХ «ХНКМ имени Л.Р. Кьзлласова» \\ (Россия, Абакан)
}

doi: 10.18411/lj-07-2020-191

idsp: ljournal-07-2020-191

Аннотация

В статье раскрыта обширная и многоплановая деятельность выдающегося врача Кызласовой Клары Романовны, которая внесла большой вклад в развитие здравоохранения в Республике Хакасия. Особое внимание авторы обратили на вклад Кызласовой в становление и развитие родовспоможения в Хакасии.

Ключевые слова: врач, роддом, здравоохранение, Хакасия, гинеколог.

\title{
Abstract
}

The article reveals the extensive and multifaceted activities of an outstanding doctor, Klara Romanovna Kyzlasova, who made a great contribution to the development of 